\title{
Studies on Algae from the Order Synurales (Chrysophyceae) in Northern Vietnam
}

\author{
Evgeniy Gusev ${ }^{1, *(\mathbb{D})}$, Nikita Martynenko ${ }^{1}$ and Hoan Tran ${ }^{2}$ \\ 1 K.A. Timiryazev Institute of Plant Physiology RAS, 35 Botanicheskaya St., 127276 Moscow, Russia; \\ nikita-martynenko@yandex.ru \\ 2 Joint Russian-Vietnamese Tropical Research and Technological Centre, 63 Nguyen Van Huyen, Nghia Do, \\ Cau Giay, Hanoi 11307, Vietnam; ecology_h@mail.ru \\ * Correspondence: gusev@ifr.moscow
}

check for updates

Citation: Gusev, E.; Martynenko, N.; Tran, H. Studies on Algae from the Order Synurales (Chrysophyceae) in Northern Vietnam. Diversity 2021, 13, 602. https://doi.org/10.3390/ d13110602

Academic Editors: Boris A. Levin, Yulia V. Bespalaya and Michael Wink

Received: 15 October 2021

Accepted: 18 November 2021

Published: 21 November 2021

Publisher's Note: MDPI stays neutral with regard to jurisdictional claims in published maps and institutional affiliations.

Copyright: (c) 2021 by the authors. Licensee MDPI, Basel, Switzerland. This article is an open access article distributed under the terms and conditions of the Creative Commons Attribution (CC BY) license (https:// creativecommons.org/licenses/by/ $4.0 /)$.

\begin{abstract}
The present paper focuses on the flora of synuralean algae from four northern provinces in Vietnam: Bac Kan, Hanoi, Ninh Binh, and Thanh Hoa. Fifty-five water bodies were studied, including territories within national parks Ba Be, Ba Vi, Cuc Phuong, Ben En, and Trang An Wetland-The World Cultural and Natural Heritage and Van Long Wetland Nature Reserve. Samples were obtained from natural lakes and wetlands, artificial reservoirs and ponds, and small temporary water bodies. Electron microscopy allowed for the discovery of 39 taxa, 37 of which belonged to the genus Mallomonas and two to the genus Synura. Six taxa of the genus Mallomonas and two taxa from the genus Synura were not identified to the lower rank. Five taxa are reported for the first time in Vietnam. The most diverse flora was observed in natural protected water bodies. Eutrophic and hypereutrophic water bodies, which were prevalent in the study area, had a reduced number of selected species.
\end{abstract}

Keywords: Northern Vietnam; tropics; freshwaters; natural protected areas; flora; Mallomonas; Synura

\section{Introduction}

The chrysophytes are unicellular or colonial algae characterized by heterokont flagella, chloroplasts with chlorophyll $a$ and $c$, and endogenous silicified stomatocysts [1]. They include about 1200 species in about 112 genera [2]. However, molecular studies show that their diversity is strongly underestimated, and many more species will certainly be described [1,3-5]. Among the species of this class, the algae of the order Synurales are distinguished by special siliceous structures, such as scales and bristles, covering the cell surface, and the genera Mallomonas and Synura are among the most diverse in the number of species from this order and all classes of Chrysophyceae. The genus Mallomonas includes more than 200 species [6,7] and Synura includes more than 50 [8]. Taking into account morphological characters and molecular data, it was proposed to distinguish synuralean algae into a separate class, Synurophyceae $[9,10]$; however, recent molecular studies of the chrysophytes phylogeny clearly showed their position among Chrysophyceae [1]. The species concept for this group is based on the morphology of siliceous structures (scales and bristles), studied by transmission or scanning electron microscopy (TEM or SEM) [3], and is considered one of the best among the protists and generally confirmed by molecular methods [11,12]. Electron microscopy studies of synuralean algae began in the 1950s [13-17]. Since then, documenting the findings of this group of algae has become mandatory, making this group the model protists for studying biogeographic issues [18-21]. About one-third of all species are of limited distribution and endemic status [22]. However, the biogeography of this group has not yet been sufficiently studied $[8,22]$. In particular, the literature on the tropical region, including its Asian distribution, is quite limited [23-29]. Studies of the tropical region often describe many new species, most of which are endemic [24,25,30-38]. Specialized research of synuralean algae in Vietnam began in 2008 [39]. Currently, the flora of the reservoirs, acidic bogs, and 
mangrove wetlands in the central Vietnamese coastal provinces [39-41] and a reservoir in the Annamese Mountains [42] have been studied. The flora of permanent and temporary water bodies of the Cat Tien National Park [43] and the Mekong Delta was also studied in Southern Vietnam [44]. These studies have revealed a very rich flora from the order Synurales, including 57 taxa from genera Mallomonas and Synura. Indeed, 19 new species from the genus Mallomonas [40,45-59] and one Synura species [60] were described in these studies. However, the northern part of Vietnam, which differs in hydrology, climate, and anthropogenic impact from the Central and Southern provinces, is lacking sufficient descriptive studies. The first studies of the region made it possible to identify and describe the unique species Mallomonas vietnamica Gusev, Kezlya \& Tran from the river Da, whose scales have morphological features characteristic of extinct fossil taxa [58]. Another species, new to science, Mallomonas siderea Gusev \& Kulikovskiy [50], was described in a reservoir in Ninh Binh Province.

The aim of this research is to study the diversity of synuralean algae in freshwaters of four provinces of Northern Vietnam with special attention to natural protected areas, and compare the taxonomic composition of different types of habitats, including natural lakes, rivers, wetlands, and artificial reservoirs and ponds.

\section{Materials and Methods}

Water samples from 55 localities in four provinces in Vietnam are included in this study (Figure 1, Table S1). Samples were taken during an expedition of the Russian-Vietnamese Tropical Centre (Ecolan 3.2 project) in 2019. In Bac Kan Province (Tỉnh Bắc Kạn), two stations in the Ba Be Lake (Hồ Ba Bể) were studied. The lake is surrounded by limestone mountains of the Ba Be National Park, which covers an area of about 45,000 ha with a strictly protected subdivision of about $3900 \mathrm{ha}$. The lake is over $8 \mathrm{~km}$ long, and ranges in width from 70 to $1300 \mathrm{~m}$ with a maximum depth of $29 \mathrm{~m}$.

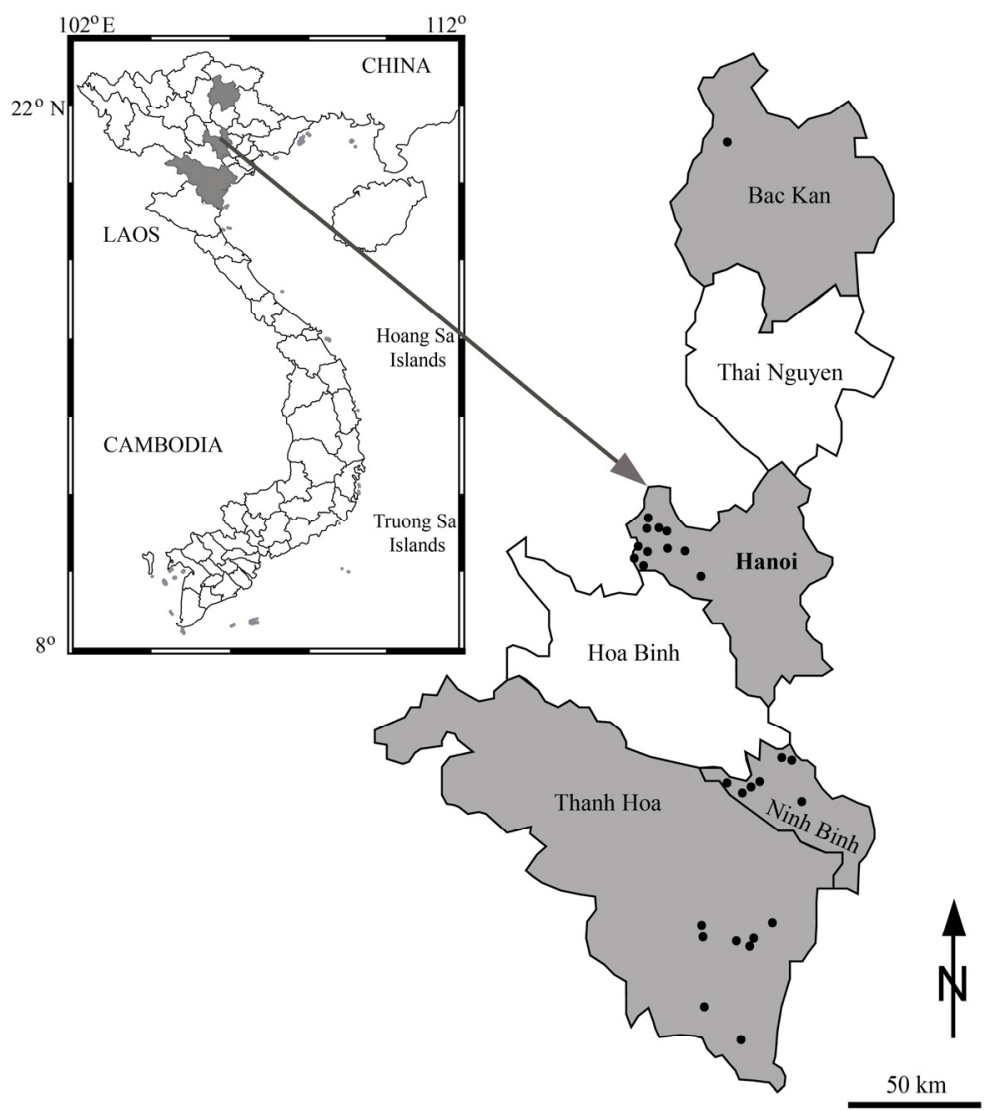

Figure 1. Geographical position of the studied area (dots are sampling areas). 
Twenty reservoirs, ponds, and channels and the Da river (Sông Đà) were investigated in the Ba Vi district, which is located in the semi-mountainous region to the northwest of Hanoi. The studied localities were all within or near the Ba Vi National Park. Unlike territories of Ba Be and Cuc Phuong National Parks, which were formed on karst terrain, the landscape of Ba Vi National Park was formed on a soil mountain with three distinct forest types: A subtropical humid evergreen forest, a combined subtropical evergreen broadleaf and coniferous forest, and a subtropical humid evergreen broadleaf forest. Within the national park, temperature decreases with altitude, and the average annual temperature is about $19-20{ }^{\circ} \mathrm{C}$ at an altitude of $500-700 \mathrm{~m}$ and decreases to $18{ }^{\circ} \mathrm{C}$ at an altitude of 900-1000 m.

In Ninh Binh Province (Tỉnh Ninh Bình), samples were collected from 21 localities, including the Van Long Wetland Nature Reserve, Trang An wetland (The World Cultural and Natural Heritage), and the Cuc Phuong National Park. The Trang An and Van Long wetlands are formed in the valleys, which are partly submerged and surrounded by karst limestone mountains. The maximum water depth is up to $5 \mathrm{~m}$. The main water sources for these wetlands are from rainwater, spring water, underground river water, and, at the same time, are influenced by the hydrological regime of the surrounding rivers Day, Boi, and Hoang Long. The Cuc Phuong National Park is located near the Trang An wetland to the west. The park is located on a karst limestone terrain with mountains rising to an altitude of $636 \mathrm{~m}$, and the foothills are surrounded by many reservoirs. Their main water sources are streams from the mountains in the park.

In Thanh Hoa Province (Tỉnh Thanh Hóa), thirteen localities have been sampled, including the Song Muc 2 Reservoir in the Ben En National Park, which is located in the southwest of Thanh Hoa Province with a total area of about 15,000 ha. In the park, the Song Muc 2 Reservoir is connected to the larger Song Muc Reservoir by a dam. The remaining sampled waterbodies were situated in residential areas and affected by human activities such as domestic wastewater, aquaculture, and agricultural cultivation.

The studied area has a monsoon tropical climate, with a rainy season from April to October and a dry season from November to March. The average annual rainfall in the region is approximately $1700-2400 \mathrm{~mm}$ and the average air temperature is approximately $25{ }^{\circ} \mathrm{C}$, with approximately 1400-1500 sunny hours per year and a mean relative humidity of $70-85 \%$.

Samples were collected from the surface water layer using a plankton net (mesh size $=20 \mu \mathrm{m})$. For electron microscopy studies, an aliquot of each sample was washed 5 times by repeated centrifugation $\left(10,000 \mathrm{rpm}\right.$ for $5 \mathrm{~min}$ at temperature $\left.20^{\circ} \mathrm{C}\right)$ in deionized water. Drops of the washed sample were dried or digested for 4-5 min in sulfuric acid with potassium dichromate. For SEM studies, samples were placed on the aluminum stubs and coated with gold for $10 \mathrm{~min}$. Observations were carried out with the JEOL $6510 \mathrm{LV}$ scanning electron microscope. For TEM studies, formvar-coated grids (EMS FF200-Cu-50, Electron Microscopy Sciences) were used and observations were made on JEM-1011. Specific conductance, $\mathrm{pH}$, and temperature measurements were performed using a Hanna HI 9828 device (Hanna Instruments, Inc., Woonsocket, RI, USA). The chlorophyll a concentrations were determined using a previously described methodology [61,62]. The classification of Nurnberg and Shaw [63] was used to assess the trophic state based on the concentration of chlorophyll a in water. The taxonomic identification was based on many works cited and discussed later in this article.

\section{Results}

A total of 39 taxa were identified in the 55 localities in Northern Vietnam (Table 1, Tables S2-S4, Figures 2-4). Thirty-seven taxa belonged to the genus Mallomonas and two taxa belonged to the genus Synura. Six taxa of the genus Mallomonas and two taxa from the genus Synura were not identified to the lower rank. All these taxa, except Synura sp. 1, are potentially new species for science. Five taxa are reported for the first time in Vietnam: Mallomonas acaroides Perty emend. Iwanoff (Figure 2A), M. ceylanica Dürrschmidt \& Cron- 
berg (Figure 2C), M. grata Takahashi (Figure 2H-M), M. parvula Dürrschmidt (Figure 3K), and M. pseudocratis Dürschmidt (Figure 4A,B. The largest number of taxa from the order Synurales was found in Thanh Hoa Province (26 taxa), followed by Ninh Binh (22 taxa), Hanoi (19 taxa), and Bac Kan Provinces (11 taxa).

Table 1. List of taxa from the order Synurales found in four provinces of Northern Vietnam. New taxa for Vietnam are given in bold, " + " indicates the presence of taxon.

\begin{tabular}{|c|c|c|c|c|}
\hline \multirow[b]{2}{*}{ Taxon } & \multicolumn{4}{|c|}{ Provinces } \\
\hline & $\begin{array}{l}\text { Bac } \\
\text { Kan }\end{array}$ & Hanoi & $\begin{array}{l}\text { Ninh } \\
\text { Binh }\end{array}$ & $\begin{array}{c}\text { Thanh } \\
\text { Hoa }\end{array}$ \\
\hline Mallomonas acaroides Perty emend. Iwanoff & + & & + & \\
\hline M. caudata Iwanoff & + & + & & + \\
\hline M. ceylanica Dürrschmidt \& Cronberg & & + & + & \\
\hline M. crassisquama (Asmund) Fott & & + & & + \\
\hline M. favosa f. favosa Nicholls & & & + & \\
\hline M. favosa f. gemina Dürrschmidt \& Croome & & & + & \\
\hline M. hexareticulata Jo, Shin, Kim, Siver \& Andersen & & + & & + \\
\hline M. grata Takahashi & & + & + & + \\
\hline M. guttata Wujek & & & + & \\
\hline M. kenyana (Wujek \& Asmund) Kapustin \& Gusev & + & + & + & + \\
\hline M. korshikovii Gusev & & & & + \\
\hline $\begin{array}{l}\text { M. lamii Gusev, Kulizin, Guseva, Shkurina \& } \\
\text { Kulikovskiy }\end{array}$ & & & & + \\
\hline M. loricata Gusev, Shkurina \& Kulikovskiy & & + & & \\
\hline $\begin{array}{l}\text { M. mangofera Harris \& Bradley var. mangofera } \\
\text { apud Dürrschmidt } 1983\end{array}$ & & + & + & + \\
\hline $\begin{array}{l}\text { M. mangofera var. foveata (Dürrschmidt) } \\
\text { Kristiansen }\end{array}$ & + & & & + \\
\hline M. cf. mangofera var. reticulata (Cronberg) & & & & \\
\hline Kristiansen sensu & + & & + & + \\
\hline $\begin{array}{l}\text { M. matvienkoae Asmund \& Kristiansen var. siveri } \\
\text { Wujek \& Saha }\end{array}$ & & & + & \\
\hline $\begin{array}{l}\text { M. minuscula Gusev, Guseva, Kezlya \& } \\
\text { Kulikovskiy }\end{array}$ & + & & & \\
\hline M. morrisonensis Croome \& Tyler & & + & + & + \\
\hline M. neoampla Gusev \& Siver & & & & + \\
\hline M. paragrandis Gusev & & & + & + \\
\hline M. parvula Dürrschmidt & & & + & \\
\hline M. peronoides (Harris) Momeu \& Péterfi & + & + & + & + \\
\hline M. portae-ferreae Péterfi \& Asmund & & + & + & + \\
\hline $\begin{array}{l}\text { M. pseudomatvienkoae Jo, Shin, Kim, Siver \& } \\
\text { Andersen }\end{array}$ & & + & & + \\
\hline M. pseudocratis Dürrschmidt & & & + & \\
\hline M. rasilis Dürrschmidt & + & + & + & + \\
\hline M. siderea Gusev \& Kulikovskiy & & & + & + \\
\hline M. spinosa Gusev emend. Wei \& Kristiansen & & & & + \\
\hline M. tonsurata Teiling & & + & + & + \\
\hline M. vietnamica Gusev, Kezlya \& Tran & & + & & \\
\hline Mallomonas sp. 1 & & + & + & + \\
\hline Mallomonas sp. 2 & & + & & + \\
\hline Mallomonas sp. 3 & & & + & + \\
\hline Mallomonas sp. 4 & + & & & \\
\hline Mallomonas sp. 5 & + & & & \\
\hline Mallomonas sp. 6 & & + & & + \\
\hline Synura sp. 1 & + & + & + & + \\
\hline Synura sp. 2 & & & & + \\
\hline Total & 11 & 19 & 22 & 26 \\
\hline
\end{tabular}



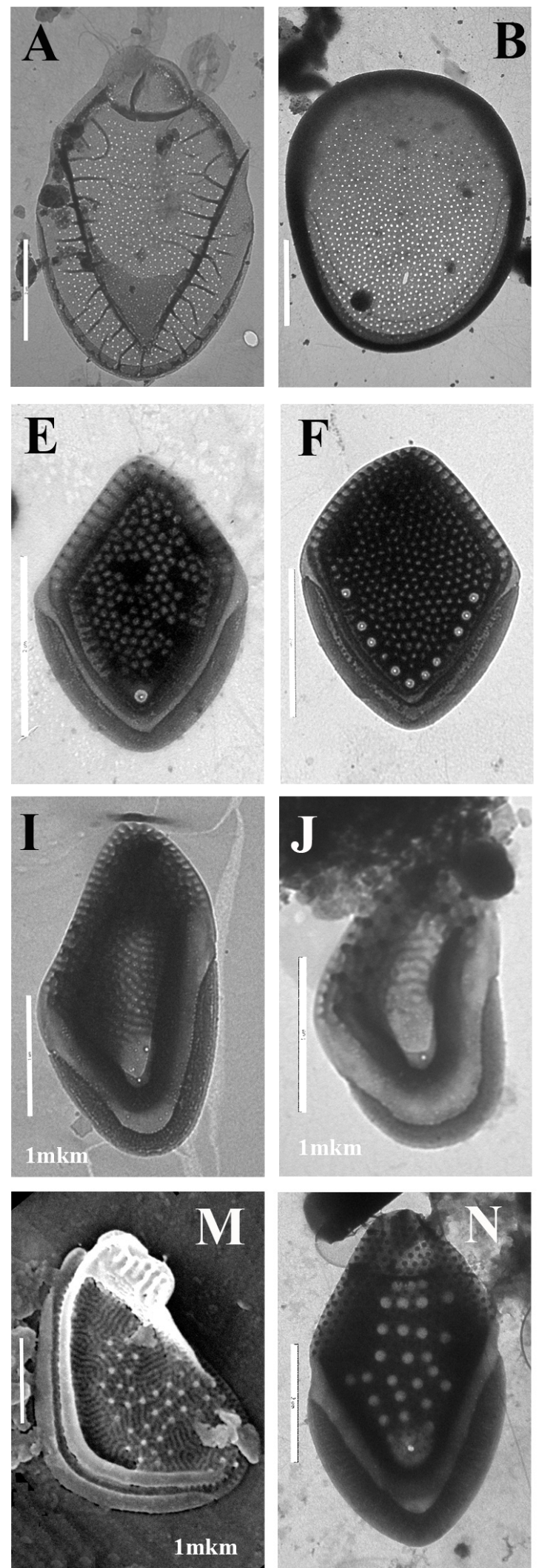
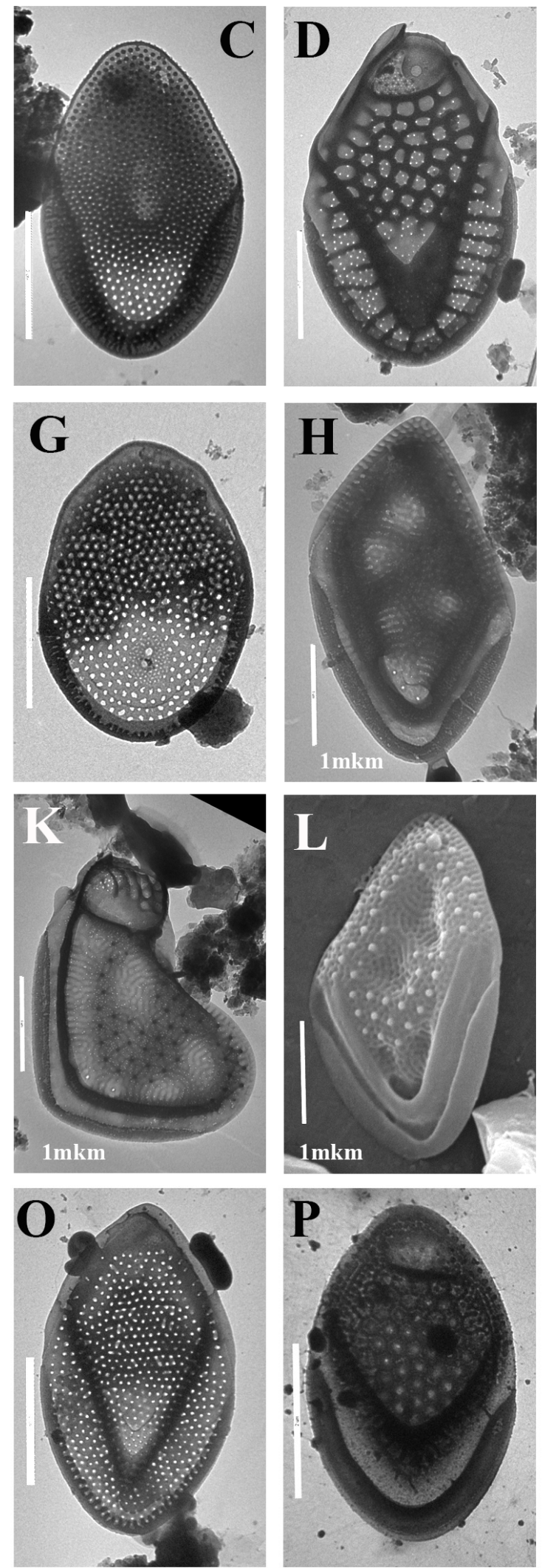

Figure 2. Mallomonas. (A). M. acaroides. (B). M. caudata. (C). M. ceylanica. (D). M. crassisquama. (E). M. favosa f. favosa. (F). M. favosa f. gemina. (G). M. hexareticulata. (H-M). M. grata. (N). M. guttata. (O). M. kenyana. (P). M. korshikovii. Scale bars: (A-G,N-P): $2 \mu \mathrm{m} ;(\mathbf{H}-\mathbf{M}): 1 \mu \mathrm{m}$. TEM: (A-K,N-P); SEM: (L-M). 

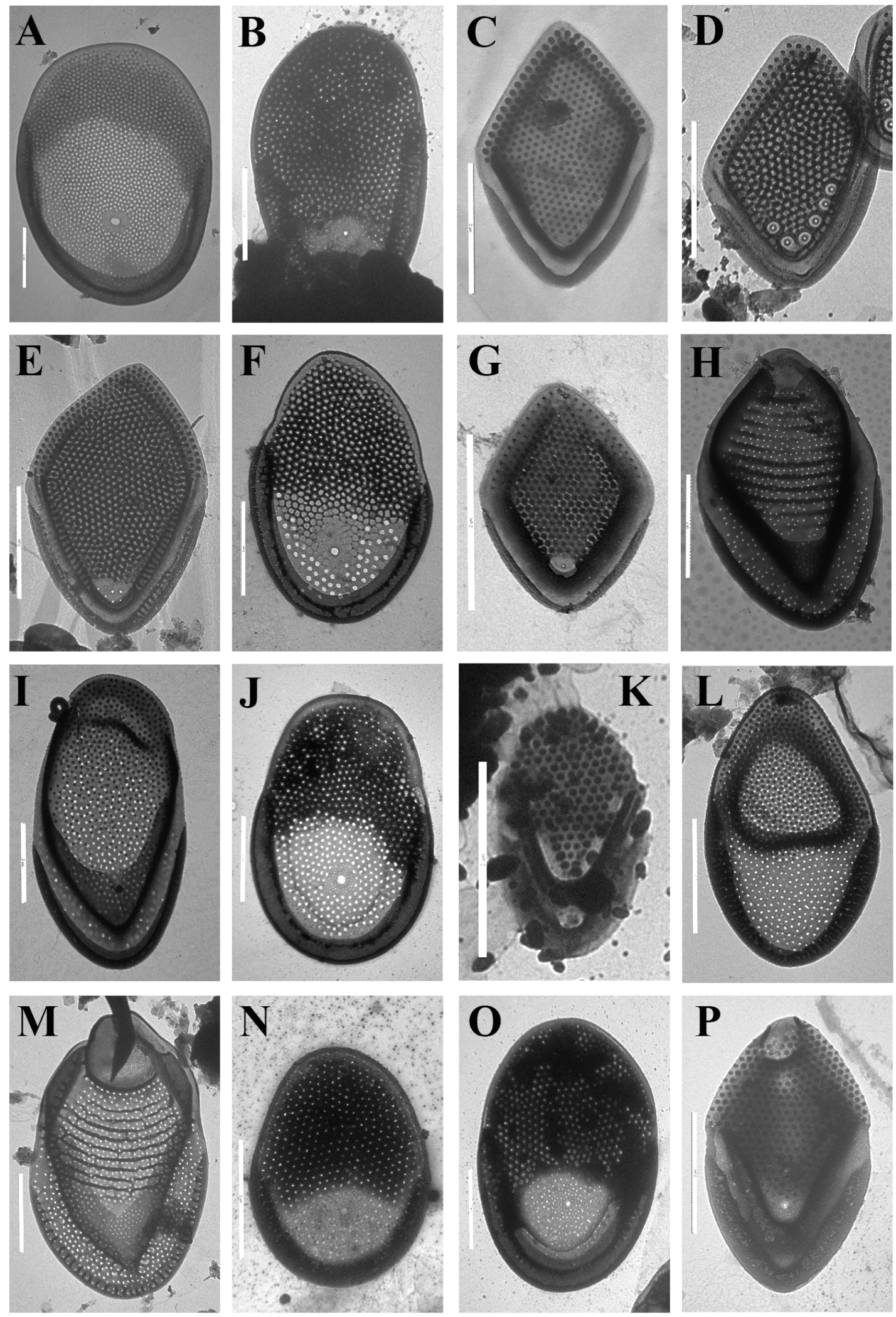

Figure 3. Mallomonas. (A). M. lamii. (B). M. loricata. (C). M. mangofera var. mangofera apud Dürrschmidt (1983). (D). M. mangofera var. foveata. (E). M. cf. mangofera var. reticulata. (F). M. matvienkoae var. siveri. (G). M. minuscula. (H). M. morrisonensis. (I). M. neoampla. (J). M. paragrandis. (K). M. parvula. (L). M. peronoides. (M). M. portae-ferreae. (N). M. pseudomatiienkoae. (O). Mallomonas sp. 6. (P). M. rasilis. Scale bars: $2 \mu \mathrm{m}$. TEM: (A-P). 

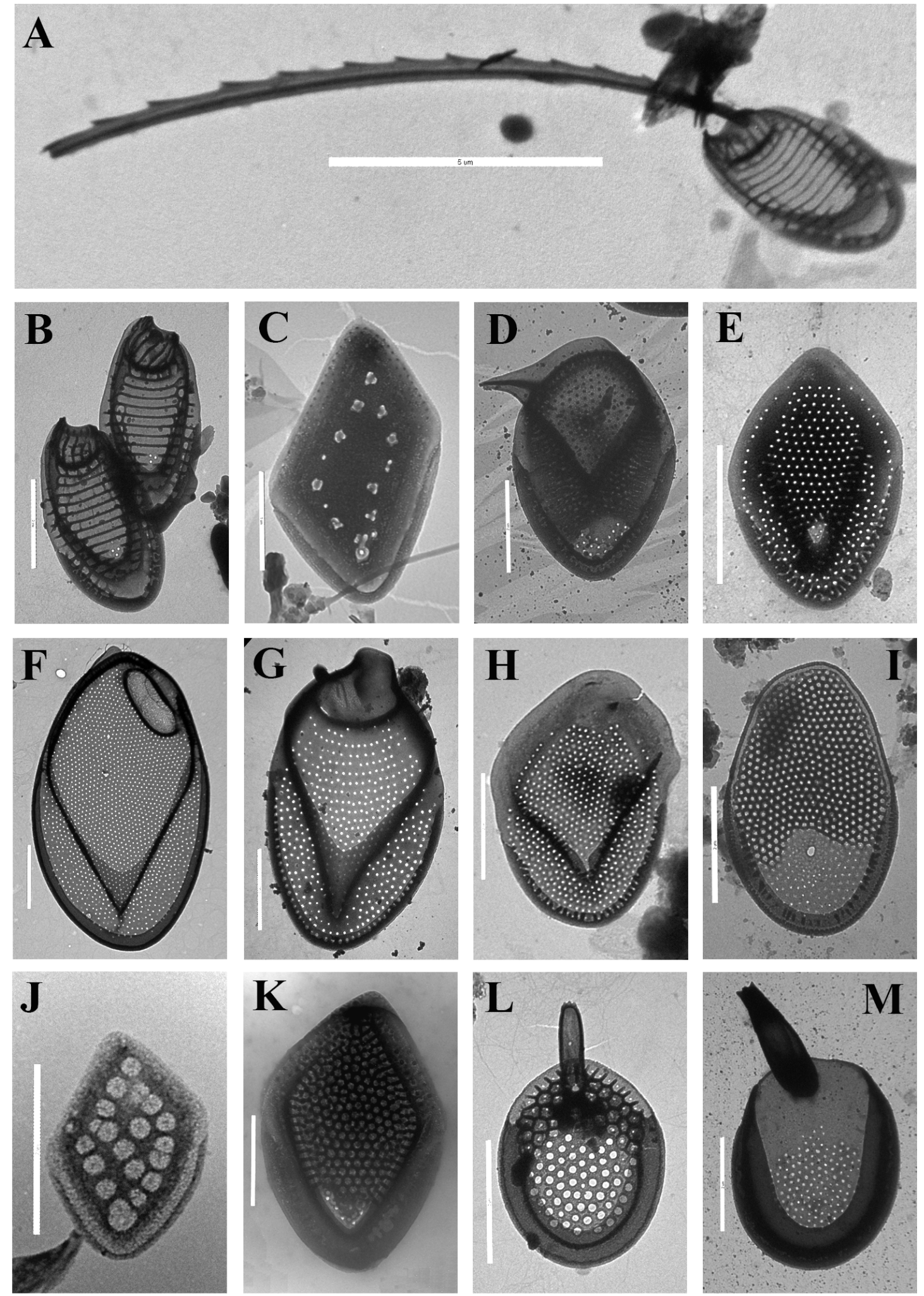

Figure 4. (A-K). Mallomonas; (L-M). Synura. (A,B). Mallomonas pseudocratis. (C). M. siderea. (D). M. spinosa. (E). M. tonsurata. (F). M. vietnamica. (G). Mallomonas sp. 1. (H). Mallomonas sp. 2. (I). Mallomonas sp. 3. (J). Mallomonas sp. 4. (K). Mallomonas sp. 5. (L). Synura sp. 1. (M). Synura sp. 2. Scale bars: (A): $5 \mu \mathrm{m}$; (B-M): 2 mm. TEM: (A-M).

Only four taxa (Mallomonas kenyana (Figure 2O), M. peronoides (Figure 3L), M. rasilis (Figure 3P), Synura sp. 1 (Figure 4L)) were recorded in all four studied provinces. Eight 
taxa were common for three provinces, 11 in two provinces, and 16 taxa were found in only one province (Table 1).

Between one and 15 taxa were found per collection site (Tables S2-S4). The highest number of synuralean taxa were found in locality 44 in Thanh Hoa Province (Table S4). Eleven taxa were reported in the Ba Be Lake in Bac Kan Province, and 10 from Trang An and Van Long Wetlands in Ninh Binh Province (Table S3). In most reservoirs, the number of species varied from one to three. Mallomonas kenyana, Synura sp. 1 and M. peronoides were the most frequently observed taxa with frequencies of occurrences at $56 \%, 49 \%$, and $36 \%$ respectively. Mallomonas sp. 1 (20\%, Figure 4G), M. tonsurata (18\%, Figure 4E), M. cf. mangofera var. reticulata (16\%, Figure 3E), M. rasilis (15\%), M. mangofera var. mangofera (15\%, Figure 3C), M. caudata (15\%, Figure 2B), Mallomonas sp. 3 (13\%, Figure 4I), M. crassisquama (11\%, Figure 2D), M. hexareticulata (11\%, Figure $2 \mathrm{G})$, and M. portae-ferreae (11\%, Figure $3 \mathrm{M})$ were quite common species in the samples. All others were observed in a few localities. Most of them were reported in water bodies located in the protected areas.

The trophic state of water bodies, assessed on the basis of chlorophyll $a$ values, varied from oligotrophic to hypereutrophic (Table S1). Most localities were eutrophic and hypereutrophic, often with cyanobacterial blooms. In Hanoi, hypereutrophic (16 localities) and eutrophic (5 localities) water bodies prevailed with a single oligotrophic locality (Da River). In Ninh Binh Province, hypereutrophic (10 localities) and eutrophic (9 localities) habitats also prevailed with five mesotrophic water bodies. In Thanh Hoa Province, there were five eutrophic and four meso- and hypereutrophic waterbodies. In general, there were significant differences in the number of taxa in water bodies of different origins and trophic states. In rivers, lakes, and wetlands of natural origin, we found between seven and fifteen taxa. In hyper- and eutrophic reservoirs and aquaculture ponds, only one to four taxa were found. In small waterbodies (puddles, temporary pools), the number of taxa varied from two to seven depending on $\mathrm{pH}$. The most characteristic taxa for hyper- and eutrophic habitats were Mallomonas kenyana, M. tonsurata, Mallomonas sp. 1, and Synura sp. 1.

\section{Discussion}

Vietnam belongs to the Indo-Burma biodiversity hotspot, 1 of the 35 areas on the Earth that have exceptionally high concentrations of endemic species and the greatest risk of their disappearance because of heavy human impacts [64]. Unfortunately, the algal diversity of Indo-Burma is still poorly understood, and so even the approximate number of species and the level of endemism are both underestimated [65]. Altogether with the previous findings [39-43], there are now fifty-seven Mallomonas taxa and five Synura taxa reported in Vietnam. Nine unidentified morphotypes of Mallomonas scales and one of Synura were also recorded in freshwaters of the country.

The new species for Vietnam's flora reported in this study can be divided into two groups. The first group consists of widespread taxa, which are common in temperate latitudes, but rare in tropical areas: Mallomonas acaroides, M. parvula, and M. pseudocratis [6]. Mallomonas acaroides was found in mountainous areas of Zimbabwe [34] and the tropics and subtropics of China $[66,67]$. Mallomonas parvula is found in the tropics and subtropics of China [66], Nigeria [68,69], and Ecuador [70]. Mallomonas pseudocratis was reported in India [27] and the tropics and subtropics of China [66,67].

The second group consists of taxa endemic to Southeast and East Asia-Mallomonas ceylanica and M. grata. Mallomonas ceylanica is a rare species from the section Planae, which was described in Sri Lanka [25]. Later, it was found in only a few localities in Hainan, China [67], India [26,27], and South Korea [11].

Mallomonas grata was one of the first species described using TEM and SEM from a pond in Japan [71]. Despite this, currently, it has been found in only a few localities. It has rare finds in India [26,27], South Korea [72], China [66,67], Singapore, and Malaysia [28]. It should be noted that TEM and SEM images used for the description were not clear enough. Subsequently, this led to errors in the identification [28] or the impossibility of identifying 
the taxon based on SEM images [72]. Therefore, we present TEM and SEM images of $M$. grata here, including body, collar, and rear scales (Figure 2H-M).

Six unidentified morphotypes of the genus Mallomonas were found during our investigations. Presumably, these are new species for science, the description of which requires more finds of scales of different types or the use of molecular methods.

Mallomonas sp. 1 (Figure 4G) belongs in the Mallomonas section and is similar in scale ultrastructure to the widely distributed $M$. elongata. Both taxa are lacking a secondary silica layer on the shield and flanges, and have a large, hooded V-rib and quite large scales. Mallomonas sp. 1, unlike M. elongata, has distinct rows of base-plate pores on the shield and a symmetric outline of scales and the V-rib. More data on the bristle structure and molecular data of Mallomonas sp. 1 is needed to clarify its taxonomy. A similar morphotype was also reported in Malaysia [24].

Another unidentified species, Mallomonas sp. 2 (Figure 4H), also belongs in the Mallomonas section. Similar scales are documented from the tropical region, most often under the species epithet Mallomonas corymbosa Asmund \& Hilliard [23,66,67]. Initially, M. corymbosa was described in Alaska [73] and later determined to have a bipolar distribution [6]. However, the morphotype of Mallomonas sp. 2 differs from M. corymbosa in the features of the development of the secondary silica layer on the shield, wide anterior margins, especially on scales without a dome, and a different structure of bristles with a long acicular end. Such scales and bristles were well illustrated in studies of silica-scaled chrysophytes in Bangladesh [23] and China [66]. In Vietnam, this morphotype was previously reported in the Mekong Delta under the name Mallomonas cf. corymbosa [44].

Mallomonas sp. 3 (Figure 4I) belongs in the section Planae. In this section, it is similar to taxa from the M. matvienkoae complex. It has ovoid scales with numerous small base-plate pores, large proximal pores, and a secondary reticulation with small rounded meshes, which covers the distal two-thirds of the scale. The Mallomonas matvienkoae complex is a complicated group, which needs typification of Mallomonas matvienkoae Asmund \& Kristiansen with molecular methods for its revision and further description of new species [59,74].

Only a few scales of Mallomonas sp. 4 were found in the Ba Be Lake (Figure 4J) and unfortunately the images quality was quite low. This taxon belongs in the section Torquatae. It has small rhomboid scales with reticulation, which consists of large circular meshes. It resembles scales of $M$. ocellat $a$ but has narrower anterior flanges with an unclear structure and smaller thickened areas inside meshes (pits). Further investigations are needed to clarify the state of this organism.

Mallomonas sp. 5 (Figure 4K) also belongs in the section Torquatae. It has rhomboid scales with reticulation and resembles taxa from the $M$. mangofera complex. The most similar species is Mallomonas lemuriocellata Hansen. Both taxa have papillae on the shield with a thickened ring around each papilla. Mallomonas sp. 5 differs from M. lemuriocellata in the presence of the reticulation on the shield and narrower ring around papillae. Further investigations, including collar and caudal scales and bristles, are necessary for delineating these taxa.

Mallomonas sp. 6 (Figure 3O) refers to a fairly common morphotype in Vietnam, where it was previously noted in the Cat Tien National Park, swamp water bodies of the Cam Ranh Peninsula, and the Mekong Delta [41,43,44]. Mallomonas sp. 6 is similar to $M$. pseudomatvienkoae and differs due to its larger scales $(5.3-5.6 \times 3.6-4.0 \mu \mathrm{m}$ versus 3-5 $\times 2-3 \mu \mathrm{m}$ in M. pseudomatvienkoae), the shape of the reticulation of the secondary silica layer in the distal part of the scales, and the presence of papillae on the shield of the scales. Molecular studies (according to unpublished data) showed the identity of this organism to be M. sp. 19 from South Korea [11]. Further research is required to describe this organism.

Synura sp. 1 (Figure 4L) represents the S. curtisipina/S. longitubularis morphotype. It is one of the most widespread taxa of synuralean algae in Vietnam, as shown both in this work and earlier (reported as Synura curtispina (Petersen \& Hansen) Asmund or S. cf. longitubularis) [41,43]. However, the identification of this taxon based on morphological 
data, like many other species of the genus Synura, is problematic [8]. Synura sp. 1 is very similar to Synura longitubularis Jo, Shin, Kim \& Siver, which was recently described in South Korea based on molecular data [75] and is almost indistinguishable from S. curtispina in terms of the morphological scales structure. Our unpublished data on 15 strains from 12 water bodies of four provinces of Vietnam, including data from the northern part of the country, using the ITS1 rDNA marker indicate that only S. longitubularis was found in water bodies of Vietnam; however, more research is needed on the distribution of this taxon.

The second unidentified morphotype of Synura was found in only one locality in Thanh Hoa Province (Figure 4M). One observed scale of Synura sp. 2 was morphologically similar to Synura morusimila Pang \& Wang [76] but differed in the presence of struts on the upturned edge and the absence of ridges at the base of the spine. Furthermore, the form of spines and small teeth on the spine's tip also differed in the investigated scale. Additional studies and more scales are necessary for correct identification. Interestingly, Synura morusimila was described and known from only three bogs in the mountainous area in China (Pang and Wang 2013).

A number of rare or interesting taxa were observed in our study. Mallomonas matvienkoae var. siveri (Figure 3F) is a very rare taxon, described in India [27], and then reported in one locality in Cat Tien National Park in Southern Vietnam [43]. Here we present the second finding in Vietnam and the third after its original description.

Mallomonas neoampla (Figure 3I) is also a rare taxon, which was described in Khanh Hoa Province, Vietnam [48]. M. neoampla represents the third taxon now known from the section Multisetigerae and it shares certain scale morphology features with the fossil species M. ampla Siver \& Lott, and others with the modern and widely distributed M. multisetigera Dürrschmidt. Here, we provide the second report for Vietnam and the third report in the world. This species was also reported in Singapore under the name "Mallomonas multisetigera" [28].

Mallomonas korshikovii (Figure 2P) is another rare species, only currently reported in its habitat from the mangrove swamp in Cam Ranh Peninsula, Vietnam [40]. Here we provide the second report of this taxon. Mallomonas korshikovii has a wide tolerance to water mineralization. In the Cam Ranh Peninsula, it was reported in a pool with salinity $1.5 \mathrm{~g} \mathrm{~L}^{-1}$, and in Northern Vietnam it was found in a low mineralized pond (approx. $0.046 \mathrm{~g} \mathrm{~L}^{-1}$ ).

Mallomonas lamii (Figure 3A), M. loricata (Figure 3B), M. minuscula (Figure 3G), and M. paragrandis (Figure 3J) were recently described in Vietnam and are widespread throughout the country $[46,47,55,57,59]$. Mallomonas loricata scales were found earlier in Malaysia and Singapore and identified as M. matvienkoae [28]. M. paragrandis was reported in Indonesia [29]. Mallomonas lamii and M. minuscula have not yet been found outside the country, but, most likely, these are fairly common species for Southeast Asia.

Mallomonas kenyana (Figure 2O) was among the most frequently observed species in our research. Interestingly, in previous studies of Vietnam (Central and Southern parts), it was reported from only one locality in the Cam Ranh Peninsula [41]. This species was described in the highly eutrophic Lake Naiwasha as a variety of $M$. cyathellata Wujek \& Asmund, Mallomonas cyathellata var. kenyana Wujek \& Asmund [77] and was later raised to the rank of species [29]. In our research, this species was the most frequently reported taxon in both eutrophic and hypereutrophic water bodies, which are prevalent in the studied area of Northern Vietnam. Generally, Mallomonas kenyana has a scattered distribution and is restricted to tropical and subtropical areas in North and South America [34,78,79], Africa $[68,69,80,81]$, and Asia $[26,27,29,66]$.

The expansion of agriculture, infrastructure development, and timber extraction are the major current threats to the biodiversity of Vietnam. Most of the territory of North Vietnam is under serious anthropogenic pressure, especially in the Da and Hong River basins, as well as in coastal areas [82-84]. In that context, the long-standing national parks and protected areas in North Vietnam such as Ba Be, Ba Vi, Cuc Phuong, Ben En, Trang An, and Van Long play an important role in conserving biodiversity in general and phytoplankton biodiversity in particular. The mentioned protected areas are the 
natural home of thousands of species, in which rare and new species are discovered every year [85-89]. The highest taxonomic diversity of synuralean algae in our study was observed in natural water bodies, most of which were located in protected areas with reduced anthropogenic impact. Most endemic and rare species were found in such habitats. Eutrophic and hypereutrophic water bodies, most of which are also artificial water bodies (reservoirs and ponds), have a reduced number of selected species. Many of them are cosmopolitan and widely distributed taxa, which replace native flora. These results again confirm the need to develop a network of protected areas, which should include entire landscape complexes of terrestrial and aquatic habitats, which will allow the preservation of not only macro-objects, but also microscopic organisms and the communities they form.

Supplementary Materials: The following are available online at https: / www.mdpi.com/article / $10.3390 / \mathrm{d} 13110602 / \mathrm{s} 1$, Table S1. Basic characteristics of the localities ( $\mathrm{pH}$, temperature, specific conductance, chlorophyll $a$ concentrations, tropic state of analyzed water bodies). Tables S2-S4. Distribution of Mallomonas and Synura species in water bodies of Hanoi, Ninh Binh, and Thanh Hoa provinces.

Author Contributions: E.G., sampling, wrote and drafted manuscript, TEM and SEM observations, identification; N.M., sample preparation, TEM and SEM observations, editing of manuscript; H.T., sampling, sample preparation, measurements, editing of manuscript. All authors contributed to the drafts and gave final approval for publication. All authors have read and agreed to the published version of the manuscript.

Funding: Financial support was provided by the Russian Science Foundation (20-14-00211) for the TEM and SEM studies, sample processing, and identification. Analysis of environmental parameters was performed within the state assignment of the Ministry of Science and Higher Education of the Russian Federation (theme No. 121041200194-7).

Institutional Review Board Statement: Not applicable.

Data Availability Statement: Not applicable.

Acknowledgments: The authors are grateful to staff of the Russian-Vietnam Tropical Centre (Hanoi, Vietnam) for their assistance in management and sampling during the project "Ecolan 3.2." In addition, we are grateful to the staff of the Centre of Electron Microscopy of Papanin's Institute for Biology of Inland Waters, RAS, for technical assistance. The authors are grateful to anonymous reviewers for their remarks that improved the manuscript.

Conflicts of Interest: The authors declare no conflict of interest.

\section{References}

1. Kristiansen, J.; Škaloud, P. Chrysophyta. In Handbook of the Protists; Springer International Publishing: Cham, Switzerland, 2017; p. 331.

2. Kristiansen, J.; Preisig, H.R. Encyclopedia of Chrysophyte genera. Bibl. Phycol. 2001, 110, 260.

3. Škaloud, P.; Kristiansen, J.; Škaloudová, M. Developments in the taxonomy of silica-scaled chrysophytes-From morphological and ultrastructural to molecular approaches. Nord. J. Bot. 2013, 31, 385-402. [CrossRef]

4. Andersen, R.A.; Graf, L.; Malakhov, Y.; Yoon, H.S. Rediscovery of the Ochromonas type species Ochromonas triangulata (Chrysophyceae) from its type locality (Lake Veysove, Donetsk region, Ukraine). Phycologia 2017, 56, 591-604. [CrossRef]

5. Bock, C.; Medinger, R.; Jost, S.; Psenner, R.; Boenigk, J. Seasonal variation of planktonic chrysophytes with special focus on Dinobryon. Fottea 2014, 14, 179-190. [CrossRef]

6. Kristiansen, J.; Preisig, H.R. Chrysophyta and Haptophyta Algae, 2nd part: Synurophyceae. In Süsswasserflora von Mitteleuropa (Freshwater flora of Central Europe); Büdel, B., Gärtner, G., Krienitz, L., Preisig, H.R., Schagerl, M., Eds.; Springer: Berlin, Germany, 2007; pp. 1-252.

7. Guiry, M.D.; Guiry, G.M.; AlgaeBase. World-Wide Electronic Publication, National University of Ireland, Galway. Available online: https: / / www.algaebase.org (accessed on 5 October 2021).

8. Škaloud, P.; Škaloudová, M.; Jadrná, I.; Bestová, H.; Pusztai, M.; Kapustin, D.; Siver, P.A. Comparing morphological and molecular estimates of species diversity in the freshwater genus Synura (Stramenopiles): A model for understanding diversity of eukaryotic microorganisms. J. Phycol. 2020, 56, 574-591. [CrossRef] [PubMed]

9. Andersen, R.A. Synurophyceae classis nov., a new class of algae. Am. J. Bot. 1987, 74, 337-353. [CrossRef]

10. Andersen, R.A. Molecular systematics of the Chrysophyceae and Synurophyceae. In Unravelling the Algae; Brodie, J., Lewis, J., Eds.; CRC Press: Boca Raton, FL, USA, 2007; pp. 285-313. 
11. Siver, P.A.; Jo, B.Y.; Kim, J.I.; Shin, W.; Lott, A.M.; Wolfe, A.P. Assessing the evolutionary history of the class Synurophyceae (Heterokonta) using molecular, morphometric, and paleobiological approaches. Am. J. Bot. 2015, 102, 921-941. [CrossRef]

12. Čertnerová, D.; Čertner, M.; Škaloud, P. Molecular phylogeny and evolution of phenotype in silica-scaled chrysophyte genus Mallomonas. J. Phycol. 2019, 55, 912-923. [CrossRef]

13. Manton, I. Observations with the electron microscope on Synura caroliniana Whitford. Proc. Leeds Phil. Soc. 1955, 6, $306-316$.

14. Petersen, J.B.; Hansen, J.B. On the scales of some Synura species. Biol. Medd. Kgl. Dan. Vid. Selsk. 1956, $23,1-27$.

15. Fott, B.; Ludvík, J. Die submikroskopische Struktur der Kieselschuppen bei Synura und ihre Bedeutung für die Taxonomie der Gattung. Preslia 1957, 29, 5-16.

16. Asmund, B. Electron microscope observations on Mallomonas caudata and some remarks on its occurrence in four Danish ponds. Bot. Tidsskr. 1955, 52, 163-168.

17. Fott, B. Scales of Mallomonas observed in the electron microscope. Preslia 1955, 27, 280-282.

18. Kristiansen, J. Cosmopolitan chrysophytes. Syst. Geog. Plants 2000, 70, 291-300. [CrossRef]

19. Kristiansen, J. Biogeography of silica-scaled chrysophytes. Nova Hedw. Beih. 2001, 122, $23-39$.

20. Barreto, S.; Kristiansen, J.; Ács, É. Silica scaled Chrysophytes during spring in the Kis-Balaton reservoir, Hungary. Acta Bot. Croat. 2000, 59, 337-349.

21. Péterfi, L.S.; Momeu, L.; Kiss, K.T.; Ács, É. Recent occurrence of Mallomonas intermedia Kisselev (Synurophyceae, Chrysophyta) in Transylvania (Romania), based on scanning electron microscopy. Acta Bot. Hung. 2005, 47, 145-149. [CrossRef]

22. Kristiansen, J. Dispersal and biogeography of silica-scaled chrysophytes. Biodivers. Conserv. 2008, 17, 419-426. [CrossRef]

23. Takahashi, E.; Hayakawa, T. The Synuraceae (Chrysophyceae) in Bangladesh. Phykos 1979, 18, $129-147$.

24. Dürrschmidt, M.; Croome, R. Mallomonadaceae (Chrysophyceae) from Malaysia and Australia. Nord. J. Bot. 1985, 5, 285-298. [CrossRef]

25. Dürrschmidt, M.; Cronberg, G. Contribution to the knowledge of tropical Chrysophytes: Mallomonadaceae and Paraphysomonadaceae from Sri Lanka. Algol. Stud. 1989, 54, 15-37.

26. Saha, L.C.; Wujek, D.E. Scale-bearing chrysophytes from tropical Northeast India. Nord. J. Bot. 1990, 10, 343-355. [CrossRef]

27. Wujek, D.E.; Saha, L.C. Scale-bearing chrysophytes (Chrysophyceae and Synurophyceae) from India. II. Nova Hedwig. 1996, 112, 367-377.

28. Neustupa, J.; Ǩezáčová, M.; Řezáčová, M. The genus Mallomonas (Mallomonadales, Synurophyceae) in several Southeast Asian urban water bodies-The biogeographical implications. Nova Hedwig. 2007, 84, 249-259.

29. Kapustin, D.A.; Gusev, E.S. Silica-scaled chrysophytes from West Java (Indonesia) including description of a new Chrysosphaerella species. Nova Hedwig. Beih. 2019, 148, 11-20. [CrossRef]

30. Compère, P. Mallomonas bronchartiana, Chrysophycée nouvelle du lac Tchad. Bull. Jard. Bot. Nat. Belg. Bull. Nat. Plantentuin Belg. 1974, 44, 61-63. [CrossRef]

31. Croome, R.L.; Tyler, P.A. Mallomonas morrisonensis (Chrysophyceae) a new species from Australia. Br. Phycol. J. 1983, 18, 383-389. [CrossRef]

32. Croome, R.; Diirrschmidt, M.; Tyler, P.A. Light and Electron Microscopical Investigation of Mallomonas splendens (G.S. West) Playfair (Mallomonadaceae, Chrysophyceae). Nova Hedwig. 1985, 41, 463-470.

33. Cronberg, G.; Hickel, B. Mallomonas fenestrata sp. nov. and M. perforata sp. nov. (Chrysophyceae, Mallomonadaceae) from tropical lakes. Nord. J. Bot. 1985, 5, 105-110. [CrossRef]

34. Cronberg, G. Scaled chrysophytes from the tropics. Nova Hedwig. Beih. 1989, 95, 191-232.

35. Hansen, P.; Kristiansen, J. Mallomonas madagascariensis, M. lemuriocellata and M. crocodilorum (Synurophyceae), three new species from Madagascar. Nord. J. Bot. 1995, 15, 215-223. [CrossRef]

36. Němcová, Y.; Bulant, P.; Kristiansen, J. Mallomonas solea-ferrea and Mallomonas siveri (Stramenopiles): Two new taxa from the Western Cape (South Africa). Nova Hedwig. 2011, 93, 375-384. [CrossRef]

37. Němcová, Y.; Kreidlová, J. Two new species of Mallomonas (Chrysophyceae: Synurales): Mallomonas temonis and Mallomonas divida. Phytotaxa 2013, 87, 11-18. [CrossRef]

38. Piątek, J. Mallomonas camerunensis sp. nov. (Chrysophyceae, Stramenopiles) from a shallow puddle in the Guineo Congolian rainforest (Cameroon). Polish Bot. J. 2015, 60, 119-126. [CrossRef]

39. Gusev, E.S.; Nguyen, T.H.T. Silica-scaled chrysophytes (Chrysophyceae and Synurophyceae) from Vietnam (Khanh Hoa and Quang Nam provinces). Nova Hedwig. 2011, 93, 191-199. [CrossRef]

40. Gusev, E.S. Studies on synurophycean algae from mangrove wetlands (Vietnam). Nova Hedwig. Beih. 2013, 142, 87-95.

41. Gusev, E.S.; Doan-Nhu, H.; Nguyen-Ngoc, L.; Guseva, E.E.; Phan-Tan, L. Silica-scaled chrysophytes from Cam Ranh Peninsula (Khanh Hoa Province, Vietnam). Nova Hedwig. Beih. 2019, 148, 63-76. [CrossRef]

42. Doan-Nhu, H.; Thi-Tinh, T.; Gusev, E.; Kulikovskiy, M.; Phan-Tan, L.; Nguyen-Ngoc, L. Taxonomic composition of silica-scaled chrysophytes in a tropical mountain reservoir. Inland Water Biol. 2021, 14, 490-499. [CrossRef]

43. Gusev, E.S.; Doan-Nhu, H.; Nguyen-Ngoc, L. Silica-scaled chrysophytes from Cat Tien National Park (Dong Nai Province, Vietnam). Nova Hedwig. 2017, 105, 347-364. [CrossRef]

44. Gusev, E.S.; Gusakov, V.A.; Guseva, E.E.; Kulikovskiy, M.S.; Tsvetkov, A.I.; Dịnh, C.N. Flora of Silica-Scaled Chrysophytes (Chrysophyceae: Synurales, Paraphysomonadales) of the Mekong Delta. Inland Water Biol. 2020, 13, 349-357. [CrossRef]

45. Gusev, E.S. A new species of the genus Mallomonas (Synurophyceae), Mallomonas spinosa sp. nov., from Vietnam. Phytotaxa 2012, 66, 1-5. [CrossRef] 
46. Gusev, E.S. A new species in genus Mallomonas Perty (Synurales, Chrysophyceae) from Vietnam. Int. J. Algae 2015, 17, 351-362. [CrossRef]

47. Gusev, E.S. A new species of the genus Mallomonas (Synurales, Chrysophyceae), Mallomonas fimbriata sp. nov. Phytotaxa 2015, 195, 291-296. [CrossRef]

48. Gusev, E.; Siver, P.A. Mallomonas neoampla sp. nov. from Vietnam, a new species that bridges the gap between fossil and modern taxa. Nova Hedwig. 2017, 104, 521-528. [CrossRef]

49. Gusev, E.S.; Kulikovskiy, M.S. Two new species of genus Mallomonas from swamp localities in Vietnam. Phytotaxa 2020, 468, 121-129. [CrossRef]

50. Gusev, E.; Kulikovskiy, M. Mallomonas siderea sp. nov. (Synurales, Chrysophyceae), a new tropical species from the section Torquatae. Nova Hedwig. 2021, 113, 291-301. [CrossRef]

51. Gusev, E.S.; Doan-Nhu, H.; Nguyen-Ngoc, L. Mallomonas cattiensis sp. nov. (Synurales, Chrysophyceae), a new species from Viet Nam. Phytotaxa 2015, 221, 188-192. [CrossRef]

52. Gusev, E.S.; Doan-Nhu, H.; Nguyen-Ngoc, L.; Kapustin, D.A. Two new species of the genus Mallomonas from the Cat Tien National Park (Viet Nam): Mallomonas distinguenda and Mallomonas skvortsovii. Phytotaxa 2016, 273, 59-64. [CrossRef]

53. Gusev, E.S.; Siver, P.A.; Shin, W. Mallomonas bronchartiana Compère revisited: Two new species described from Asia. Cryptogam. Algol. 2017, 38, 3-16. [CrossRef]

54. Gusev, E.S.; Čertnerová, D.; Škaloudová, M.; Škaloud, P. Exploring Cryptic Diversity and Distribution Patterns in the Mallomonas kalinae/rasilis Species Complex with a Description of a New Taxon Mallomonas furtiva sp. nov. J. Eukaryot. Microbiol. 2018, 65, 38-47. [CrossRef]

55. Gusev, E.; Guseva, E.; Kezlya, E.; Kulikovskiy, M. Mallomonas minuscula sp. nov. (Synurales, Chrysophyceae), a new member in the section Torquatae from Vietnam. Fottea 2019, 19, 132-137. [CrossRef]

56. Gusev, E.S.; Kapustin, D.A.; Martynenko, N.A.; Guseva, E.E.; Kulikovskiy, M.S. Mallomonas gusakovii sp. nov. (Chrysophyceae, Synurales), a new species from Phu Quoc Island, Vietnam. Phytotaxa 2019, 406, 199-205. [CrossRef]

57. Gusev, E.; Kulizin, P.; Guseva, E.; Shkurina, N.; Kulikovskiy, M. Mallomonas lamii sp. nov. (Synurales, Chrysophyceae), a new species bearing large scales described from the tropics. Phytotaxa 2019, 423, 266-272. [CrossRef]

58. Gusev, E.; Kezlya, E.; Tran, H.; Kulikovskiy, M. Mallomonas vietnamica sp. nov. (Synurales, Chrysophyceae), a new species, that shares some features with fossil taxa. Cryptogam. Algol. 2021, 42, 39-46. [CrossRef]

59. Gusev, E.; Shkurina, N.; Kulikovskiy, M. Mallomonas loricata sp. nov. (Synurales, Chrysophyceae), a new tropical species from section Plantae. Phytotaxa 2021, 500, 225-233. [CrossRef]

60. Siver, P.A.; Kapustin, D.; Gusev, E. Investigations of two-celled colonies of Synura formerly described as Chrysodidymus with descriptions of two new species. Eur. J. Phycol. 2018, 53, 245-255. [CrossRef]

61. Clescerl, L.S.; Greenberg, A.E.; Eaton, A.D. Standard Methods For The Examination Of Water and Wastewater, 20th ed.; American Public Health Association: Washington, DC, USA, 1999; pp. 1-1325.

62. Rowan, K.S. Photosynthetic Pigments of Algae; Cambridge University Press: Cambridge, UK, 1989; 334p.

63. Nürnberg, G.K.; Shaw, M. Productivity of clear and humic lakes: Nutrients, phytoplankton, bacteria. Hydrobiologia 1999, 382, 97-112. [CrossRef]

64. Mittermeier, R.A.; Turner, W.R.; Larsen, F.W.; Brooks, T.M.; Gascon, C. Global Biodiversity Conservation: The Critical Role of Hotspots. In Biodiversity Hotspots: Distribution and Protection of Conservation Priority Areas; Zachos, F.E., Habel, J.C., Eds.; Springer: Berlin, Germany, 2011; pp. 3-22.

65. Vyverman, W. The Indo-Malaysian North-Australian phycogeographical region revised. Hydrobiologia 1996, 336, 107-120. [CrossRef]

66. Wei, Y.X.; Yuan, X.P. Studies on silica-scaled chrysophytes from the tropics and subtropics of China. Nova Hedwig. Beih. 2001, $122,169-187$.

67. Wei, Y.X.; Yuan, X.P.; Kristiansen, J. Silica-scaled chrysophytes from Hainan, Guangdong Provinces and Hong Kong Special Administrative Region, China. Nord. J. Bot. 2014, 32, 881-896. [CrossRef]

68. Wujek, D.E.; Adesalut, A.; Nwankwo, D.I. Silica scaled Chrysophyceae and Synurophyceae (Chrysophyta) from Nigeria. II. Lake Lekki. Trop. Freshwat. Biol. 2003, 12, 99-103. [CrossRef]

69. Wujek, D.E.; Kadiri, M.O.; Dziedzic, R.M. Silica-scaled Chrysophyceae and Synurophyceae from Nigeria. III. Chrysophytes from rivers of Edo State. Fottea 2010, 10, 93-98. [CrossRef]

70. Wujek, D.E.; Dziedic, R.M. Silica-scaled Chrysophytes from Ecuador. Gayana Bot. 2005, 62, 1-8. [CrossRef]

71. Takahashi, E. Studies on genera Mallomonas, Synura and other plankton in fresh-water with electron microscope. IV. On two new species of Mallomonas found in ditches at Tsuruoka in North-East of Japan. Bull. Yamagata Univ. Agric. Sci. 1963, 4, 169.

72. Kim, J.H.; Kim, H.S. Seasonal occurrence of silica-scaled chrysophytes in a small eutrophic swamp, South Korea. Nova Hedwig. Beih. 2011, 93, 411-436. [CrossRef]

73. Asmund, B.; Hilliard, D.K. Studies on Chrysophyceae from some ponds and lakes in Alaska. I. Mallomonas species examined with the electron microscope. Hydrobiologia 1961, 17, 237-258. [CrossRef]

74. Jo, B.Y.; Shin, W.; Kim, H.S.; Siver, P.A.; Andersen, R.A. Phylogeny of the genus Mallomonas (Synurophyceae) and descriptions of five new species on the basis of morphological evidence. Phycologia 2013, 52, 266-278. [CrossRef]

75. Jo, B.Y.; Kim, J.I.; Škaloud, P.; Siver, P.A.; Shin, W. Multigene phylogeny of Synura (Synurophyceae) and descriptions of four new species based on morphological and DNA evidence. Eur. J. Phycol. 2016, 51, 413-430. [CrossRef] 
76. Pang, W.; Wang, Q. A new species, Synura morusimila sp. nov. (Chrysophyta), from Great Xing'an Mountains, China. Phytotaxa 2013, 88, 55-60. [CrossRef]

77. Wujek, D.E.; Asmund, B. Mallomonas cyathellata sp. nov. and Mallomonas cyathellata var. kenyana var. nov. (Chrysophyceae) studied by means of scanning and transmission electron microscopy. Phycologia 1979, 18, 115-119.

78. Wujek, D.E. Chrysophyceae (Mallomonadaceae) from Florida. Fla. Sci. 1984, 3, 160-170.

79. Franceschini, I.M.; Couté, A.; Silva, A.J. Synurophyceae et Chrysophyceae à écailles siliceuses du rio dos Sinos, RS, Brésil. Algol. Stud. 1996, 80, 59-85.

80. Cronberg, G. Mallomonas stellata, a new silica-scaled chrysophycean from Zimbabwe. Kirkia 1988, 13, $143-152$.

81. Hansen, P. Silica-scaled Chrysophyceae and Synurophyceae from Madagascar. Arch. Protist. 1996, 147, 145-172. [CrossRef]

82. Le, T.P.Q.; Ho, T.C.; Duong, T.T.; Nguyen, T.B.N.; Vu, D.A.; Pham, Q.L.; Seidler, C. Water quality of the Red River system in the period 2012-2013. J. Vietnam. Environ. 2014, 6, 191-195. [CrossRef]

83. Hoang, T.T.H.; Nguyen, T.K.; Le, P.Q.; Dang, D.K.; Duong, T.T. Assessment of the water quality downstream of Red River in 2015 (Vietnam). J. Vietnam. Environ. 2015, 8, 167-172. [CrossRef]

84. Petrisor, A.; Hamma, W.; Nguyen, H.D.; Randazzo, G.; Muzirafuti, A.; Stan, M.; Tran, V.T.; Astefănoaiei, R.; Bui, Q.; Drago, V.D.; et al. Degradation of Coastlines under the Pressure of Urbanization and Tourism: Evidence on the Change of Land Systems from Europe, Asia and Africa. Land 2020, 9, 275. [CrossRef]

85. Le, D.T.; Nguyen, T.Q.; Le, M.D.; Ziegler, T. A new species of Cyrtodactylus (Squamata: Gekkonidae) from Ninh Binh Province, Vietnam. Zootaxa 2016, 416, 268-282. [CrossRef]

86. Chen, W.H.; Radbouchoom, S.; Nguyen, H.Q.; Nguyen, H.T.; Nguyen, K.S.; Shui, Y.M. Seven new species of Begonia (Begoniaceae) in Northern Vietnam and Southern China. PhytoKeys 2018, 94, 65-85. [CrossRef] [PubMed]

87. Dang, V.S.; Naiki, A. Two New Species of Lasianthus (Rubiaceae) from Northern Vietnam. Ann. Bot. Fenn. 2020, 57, 49-54. [CrossRef]

88. Tran, T.B.; Le, N.H.; Do, V.H.; Bui, H.Q.; Nguyen, T.T.H.; Bui, T.H.; Tran, V.H.; Rodda, M. Heterostemma cucphuongense (Apocynaceae, Asclepiadoideae), a new species from Vietnam. PhytoKeys 2020, 148, 119-124. [CrossRef] [PubMed]

89. Hoang, T.B.; Nguyen, V.N.; Hoang, T.S.; Shuichiro, T.; Tetsukazu, Y. Quercus ngochoaensis (Fagaceae), a new species from Ba Vi National Park, northern, Vietnam. Phytotaxa 2021, 516, 283-288. 